\title{
RESURGENT CHINA AND ECONOMIC IMPLICATIONS FOR ASEAN
}

\author{
Syeda Parnini
}

\section{Introduction}

In recent years, China's influence in Asia has increased remarkably both in economic and military terms and the strengthening of soft power and hard power of Beijing have been pivotal in expanding the country's regional influence. After the end of the Cold War, the resurgence of China is gradually more explicit as it has emerged as an economic giant to dominate the economic agenda in the Asia-Pacific and this has economic implications for the Association of Southeast Asian Nations (ASEAN). This paper explores the development of Southeast Asia's relations with the People's Republic of China (PRC) in recent years showing how economic and political concerns associated with China's peaceful rise have been a significant factor in shaping policies of the Association of Southeast Asian Nations (ASEAN) and its member countries. In addition, the paper analyzes the institutionalization of linkages between ASEAN and China in the contemporary world particularly after the Asian financial crisis in 1997 enabling the formation of ASEAN Plus Three. The key focus of this paper is the economic dimension of ASEAN-China relations in a rapidly changing scenario of the Asian Pacific region in the $21^{\text {st }}$ century.

There has been a long-held experience of the states of Southeast Asia in relation to China and according to C.P. Fitzgerald, "Chinese influence, Chinese culture and Chinese power have always moved southward since the first age of which they have reliable historical evidence." Although geopolitically China is in Northeast Asian, it has a close tie with Southeast Asia particularly senior leaders in Beijing have always tended to view Southeast Asia as China's leg. But, China has resisted exerting any subregional hegemony in Southeast Asia. ${ }^{1}$

China has experienced fast economic growth since the late 1970s. It is increasingly exposed to the world as well as spawning a new Chinese activism in Southeast Asia, of which the past few years provide some initial manifestations. Chinese economic activism has always been welcomed by the states of Southeast Asia. However, Chinese military buildup is less welcomed by those states as they fear a nagging uncertainty over the long-term potential for such activism and the effect it might have on regional security and stability. Lately, ASEAN-China relations have become important as both

1 J., Haacke, “The Significance of Beijing's Bilateral Relations: Looking 'Below' the Regional Level in China-ASEAN Ties," in H. K. Leong \& S. C. Y. Ku (Eds.), China and Southeast Asia: Global Changes and Regional Challenges. Singapore, Institute of Southeast Asian Studies, 2005, pp116. 
are concerned with regional peace and stability, which are key determinants to economic prosperity of both China and ASEAN in the era of globalization.

\section{Geopolitical Dynamics of China and Southeast Asia}

Currently, many common interests seem to unite China and the countries of Southeast Asia and apparently economics is the key driving force of the relationship between China and ASEAN. China's rapid economic growth is providing ample opportunities to the countries of ASEAN, which have stepped up trade and investment links significantly with the People`s Republic of China (PRC). The Chinese growth phenomenon comes at a time when Japan's economy has is experiencing structural problems, leaving it in the trough of the economic cycle. In Southeast Asia, therefore, there is a widespread perception that China will be the new engine of growth for the entire region, displacing Japan, which had played that role for the past thirty years or more. The allure of substantial economic benefits arising out of China's developmental boom has even impelled those Southeast Asian states which were cool towards Beijing, such as Malaysia and Indonesia, to exploit the long-term possibilities inherent in China's rapid modernization. China and ASEAN are willing to downplay sensitive issues so as to secure mutual benefits.

The territorial dispute over the Spratly Islands is the most prominent problem afflicting China and four ASEAN States, namely Vietnam, the Philippines, Malaysia, and Brunei. These claimant claim all or part of the Spratlys, together with Taiwan, have in recent years attempted to quietly shore up their ability to enforce their claims to these islands. Part of the current Southeast Asian defense modernization and expansion program is a consequence of contingency planning related to the Spratlys. Indonesia's sources of diplomatic tension with China involve the issue of the so called "Overseas Chinese" in Indonesia and China's overarching claim to much of the South China Sea, which appear to include part of Indonesia's Natuna islands. China's increasing economic cooperation with ASEAN in terms of trade and investments through ChinaASEAN Free Trade Area (CAFTA) suggests a positive relationship between the two sides. This state of affairs, however, may not necessarily be sustained unless political and security stabilities are ensured, given that broader geopolitical changes in the AsiaPacific could modify the complexion of the relationship, particularly in the longer term. In 2010, China-ASEAN Free Trade Area (FTA) was launched, which was ASEAN's first FTA with an external party. The CAFTA has the largest consumer market size with 1.9 billion consumers and a GDP of US\$9.4 trillion in 2011. Since 2009, China has overtaken the EU and Japan as ASEAN's largest trading partner, while ASEAN ranks as China's third- largest trading partner. However, this kind of economic prospects are essentially dependent on the peace and overall security of the Asian region. Despite the negotiation of a Declaration on the Code of Conduct in 2002, there remain internal divisions within ASEAN on the issue and Vietnam and Philippines continue to be wary of Chinese encroachment. Individually, none of the ASEAN states have military capabilities that could successfully oppose a determined Chinese advance into the South China Sea, and they are unlikely to have such capabilities in the foreseeable future. Consequently, there is a real but silent fear in Southeast Asia attached to the directions in China's modernization programs and its operational doctrine. 


\section{Rise of China and Norms of ASEAN}

China remains a "status quo state" rather than a "revisionist state" as it is not trying to change the "rule of game". ${ }^{2}$ It, however, seems that the assessments of China's commitment to ASEAN norms as a member of the "international community" remain suspicious to realists. ${ }^{3}$ Despite the serious disagreement among realists, China's engagement with ASEAN has to be recognized as a case underpinning "China's peaceful ascendancy" since there has been as yet an absence of fierce conflicts in the region. The adoption of the ASEAN Way by China is perhaps the most important development insofar as constructivists are concerned. It is often considered as an alternative world order as the norms of a small countries' group, ASEAN, incorporating non-interference, peaceful resolution efforts, respecting sovereignty, and respecting ASEAN's centrality in regionalism and multilateralism have been received and accepted by a global power, China. ${ }^{4}$

There are several reasons for claiming China's peaceful engagement and respect for ASEAN norms. It is argued that a notable example of that can be found in the process of the ASEAN Regional Forum (ARF) where significant improvements in the relations between China and ASEAN through regular socialization. ${ }^{5}$ China was the first country from outside the region to accede to the Treaty of Amity and Cooperation (TAC) in 2003, which led the way for other countries to follow. On the South China Sea issue, China has signed major agreements for peaceful settlements although the matter remains unsolved. In the economic sector, trade between China and ASEAN has increased in favor of the latter in terms of trade balance. ${ }^{6}$ In fact, China was the first country to sign a Free Trade Agreement (FTA) with ASEAN as a collective unit in November 2002. At the same time, bilateral relations with individual ASEAN member states have also been largely improved. It is obvious that China's trade with ASEAN has been expanding every year (see Table-1).

2 A.I., Johnston, " Social States: China in International Institutions 1980-2000", 2007.

3 D.M Jones, M.L.R. Smith, "Constructing communities: the curious case of East Asian regionalism", Review of International Studies, Vol 33, No.1.

4 A.I., Johnston, " Social States: China in International Institutions 1980-2000", 2007.; D., Shambaugh, "China Engages Asia: Reshaping the Regional Order", International Security, 2004, Vol 29, No. 3; R., Stubbs, "The ASEAN alternative? Ideas, institutions and the challenge to 'global' governance", The Pacific Review, Vol 21, No.4, 2008.

5 A.I., Johnston, " Social States: China in International Institutions 1980-2000", 2007, pp. 160181; H., Katsumata, "Establishment of the ASEAN Regional Forum: constructing a 'talking shop' or a 'norm brewery", The Pacific Review, Vol 19 No. 2, 2006, pp 181 - 198.

6 H., Katsumata, "Correspondence: ASEAN, Regional Integration, and State Sovereignty", International Security, Vol 33, No. 2, 2008. 
Table 1: ASEAN's trade with China 2007-2011: USD at current prices (millions)

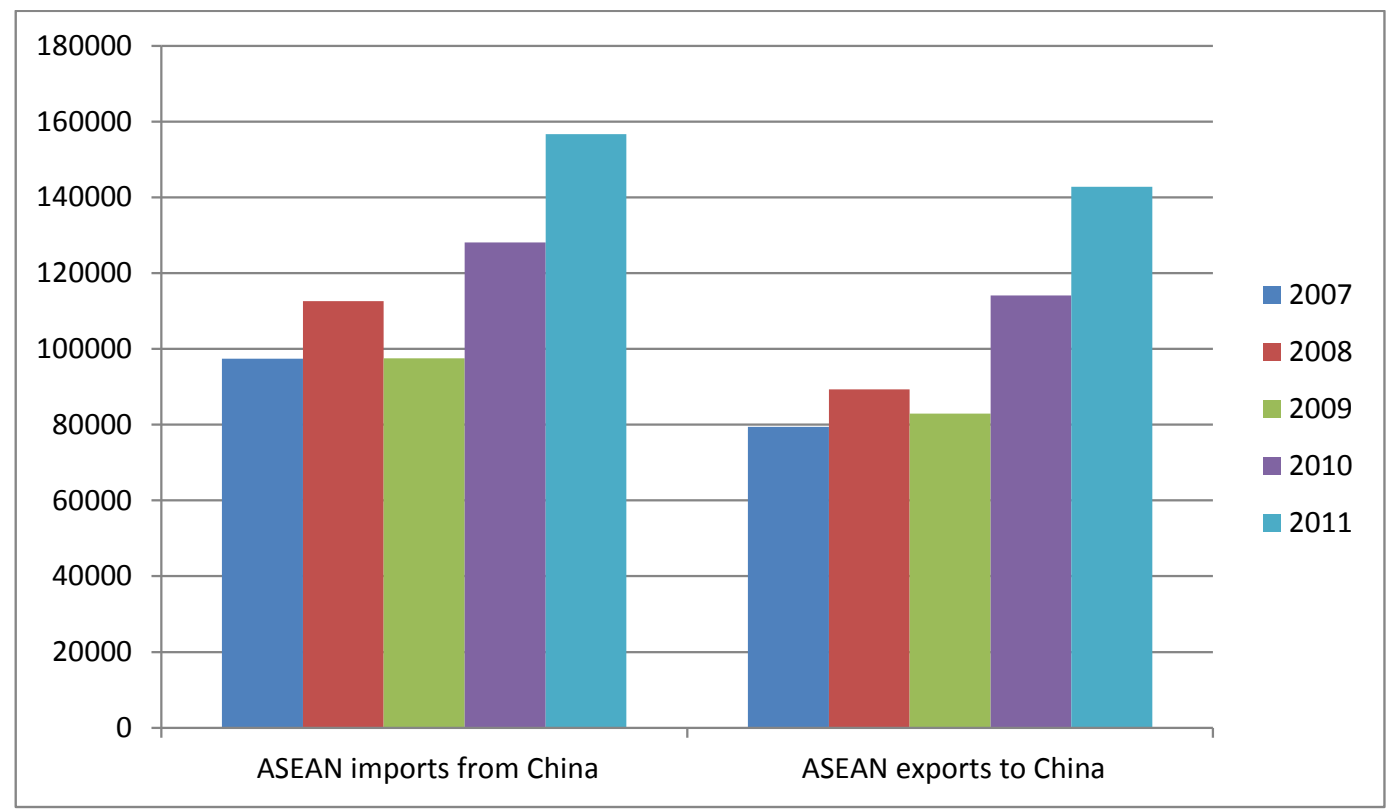

Source: data compiled from WTO trade statistics

Despite China's successful moves towards socialization, ASEAN's perception and response to China's actions still matter. ASEAN as a group of small countries may prefer to be "bandwagoning" or "balancing" China. Observation and assessment of the collective reaction of ASEAN has been complex, while individual responses of member states render these arguments controversial. Since the responses from ASEAN member states is often in mixed forms without clear evidence to support any one argument, this led to a new conceptual understanding, "hedging", an alternative to "bandwagoning" and "balancing". ${ }^{7}$ However while China's trajectory has shown a certain level of commitment without critical breach of norms, some suspicious circles argue that China would change its approach after achieving its strategic goals in the long term. For many of the ASEAN member states, China's favorable engagement with ASEAN is a relatively new development in comparison to the long-standing antagonism of many Southeast Asian countries towards China. These sentiments had their origins in the history of the tributary system and the ideological and security threats during the Cold War. Some scholars emphasize the matter of perception in the confidence building process with China. Accordingly, any commitment by China in the APT process often raises doubts as to the real intentions of the country. This account implies that although China is committed as a good partner so far, it has failed to get enough trust from the related

7 C., Kuik, "The essence of hedging: Malaysia and Singapore's response to a rising China", (Report), Contemporary Southeast Asia, Vol 30, No. 2, 2008,pp 127; J.C., Liow, "Balancing, Bandwagoning, or Hedging? Strategic and Security Patterns in Malaysia's Relations with China 1981-2003", in H. K. L. a. S. C.Y.Ku (Ed.), China and Southeast Asia: Changes in Strategic Perceptions Singapore, Institute of Southeast Asian Studies, 2005. 
parties that are in various strategic positions. China has shown its political will for the peaceful settlement of conflicts in the region and respecting territorial sovereignty mainly under the aegis of the non-interference principle.

However, it was not an existing norm for China at the beginning of its engagement with ASEAN. It was absorbed through an incremental evolution process rather than with the changes in the domestic and international conditions. In practical terms, at least until the end of 1960s, China never gave up a certain degree of interference in her foreign policy. ${ }^{8}$ The end of the Cold War was certainly an important catalyst accelerating China's internal economic reforms towards a market economy under the Chinese Communist Party's direction.

After decades of antagonism and conflicts with Vietnam, the end of the Cold War initially would mean the isolation of China from the world. For strategic reasons, China has been sensitive to the penetration of external powers into the region through the establishment of military bases in the region. As economic development was crucial for maintaining the legitimacy of the China Communist Party's rule, political stability through economic growth became the major concern. Thus China has resisted exerting any sub-regional hegemony in Southeast Asia. ${ }^{9}$ As an external factor, in particular, American Asian policy has been a determinant historical and structural factor for the relations between China and Southeast Asia.

As mentioned, the restoration of diplomatic relations in the 1970s between some member states of ASEAN and China was the result of the reconciliation between the US and China. The US remains one of the most important factors determining the China-ASEAN relations. China has not simply adopted the ASEAN norms. While China has tried to show its respect for ASEAN norms and centrality, it has simultaneously revitalized its own norms such as the Five Principles of Peaceful Coexistence enshrined by Chu En Lai in 1950s, the Policy of Good Neighborliness (PGN) in the mid-1980s, and the New Security Concept (NSC) in 1997 along with the universal norms of the Charter of the United Nations. For instance, in the Joint Statement in 1997, China affirmed that "the Charter of the United Nations, the Treaty of Amity and Cooperation in Southeast Asia, the Five Principles of Peaceful Coexistence and universally recognized international law should serve as basic norms governing their relations. In fact, without mentioning the originator and specific requirements for making an exceptional case,

They reaffirmed in particular their respect for each other's independence, sovereignty and territorial integrity and the principle of non-interference in the internal affairs of other states. ${ }^{10}$

As operational norms, the agreement was not much different from the way in which ASEAN had conducted itself, which included the principles of mutual understanding, consensus, consultation, and cooperation. In a relatively recent case of the Joint Declaration of ASEAN and China on Cooperation in the Field of non-traditional security Issues, the notion of the Five Principles of Peaceful Coexistence was first stated ahead of other norms. The adherence to the ASEAN norms was not solely China's unilateral

8 J., Haacke, “The Significance of Beijing's Bilateral Relations: Looking 'Below' the Regional Level in China-ASEAN Ties," in H. K. Leong \& S. C. Y. Ku (Eds.), China and Southeast Asia: Global Changes and Regional Challenges. Singapore, Institute of Southeast Asian Studies, 2005, pp112.

$9 \quad$ Ibid., pp116.

$10 \quad$ Ibid., pp116. 
concession. In return, since 1997, ASEAN members have collectively reaffirmed their continued adherence to the "one China" policy.

The linkage between China and Southeast Asia represents a cultural notion of Asia versus the West. As China's cultural diplomacy was an important step to engage deeply in Indonesia during Sukarno's presidency, China's approach to ASEAN is also very much alike in tradition. ${ }^{11}$ For instance, China had dispatched delegations to ASEAN to learn the ASEAN way of doing business. It echoed the 'Asian Values' or 'Asian Way' as advocated by the leaders of Singapore and Malaysia. While this may be the subject of controversial debates, China may add weight to the concept of Asian values which basically emphasizes the traditions of Confucianism. And it is often camouflaged to counter Western criticism. For instance, it has been said that the ASEAN-China concord contributed to prevent the Western countries from compelling ASEAN to change its policy on human rights issues such as in Myanmar. ${ }^{12}$ The unconditional implementation of ASEAN's non-interference principle and consensus is an indication of China's commitment to the ASEAN Way.

\section{Common Interests of China and ASEAN}

The bilateral relationship between Beijing and the regional grouping has been getting closer, adding that both sides are keen in promoting peace and stability in the region and have realized the role of regional security in the region's overall economic development. No single policy or strategy has been adopted by the Southeast Asian states in their attempts to deal with China's rise as a major power. Rather, these states have adopted a number of individual and collective policies and strategies, whose main objectives are to provide a moderating influence on Chinese regional behavior while simultaneously affording ample opportunities for these states to benefit from China's developmental boom. Some of the Southeast Asian states believe that the rubric of economics can help keep China benign. Burgeoning trade and investment linkages have their obvious benefits to the economies of both the ASEAN states and China. Such linkages also have an indirect security element. The increasing interdependence of the economies of Southeast Asia and China has the effect of giving Beijing a stake in the peace and stability of the region.

The question is whether Beijing would put its economic goals at risk by displays of military power or the overt use of force. There are two contending views on this question. One assumes that if China achieves greatness via the economic route, its political and diplomatic influence through 'soft power' will be sufficient enough to shape the future course of events in the region, obviating the need to assert itself militarily. The other view contends that China wants it all: economic greatness and territorial aggrandizement through force of arms. Thus, any notion that Southeast Asia's security can eventually become indivisible from China is a mere chimera. The first perspective seems to have certain validity in the near and medium term. The second perspective might well have resonance in the longer term. The ASEAN states are no doubt aware of both possible outcomes. That is why they seem to have adopted a strategy of buying as much time as

11 H., Liu, "The Transnational construction of "national Allegory": China and the Cultural Politics of Postcolonial Indonesia", Critical Asian Studies, Vol 38, No. 3, 2006.

12 H., Katsumata, "Correspondence: ASEAN, Regional Integration, and State Sovereignty", International Security, Vol 33, No. 2, 2008, pp 184. 
possible for the region, while enjoying the benefits of Chinese economic growth, before the medium term begins the transition to the longer term.

The largely apparent dimension is premised on the fact that the states of Southeast Asia accept that Taiwan is a domestic issue of China. Consequently, during the "crisis" in the Taiwan Strait they did not feel that it was their place to be seen interfering in the domestic affairs of another country - an avowed ASEAN principle of 'Asian Way'. The Southeast Asian states are only too aware of the proximity of growing Chinese power, and being pragmatic they have apparently decided that the best course of action is to reconcile them to that fact and to accommodate China's rise. Regional reaction has been reflecting more a desire not to upset China and miss commercial opportunities offered by its huge and growing market than by any confidence in Beijing's intentions. By this essentially expedient stance, the ASEAN states incur few costs, at least in the near-to-medium terms.

ASEAN's more active approach in dealing with an increasingly powerful China has been to "engage" it within a multilateral security structure, namely the ASEAN Regional Forum (ARF). As Michael Leifer stated, "When the senior official of ASEAN and its dialogue partners convened at a seminal meeting in Singapore in May 1993, which led to the ARF, balance of power as well as the ASEAN model were very much in mind with China identified as a potential hegemon". ${ }^{13}$ The object of the exercise was not necessarily to contain China. Indeed, it was hoped that the nexus of economic incentive would serve to bring about the constructive engagement which has become part of regional agenda.

Thus, one of the key aims of the ARF has been to bring China into a security structure with the hope that it would then operate within that framework, taking cognizance of the interests and sensitivities of other ARF members; in other words, to lock China into a constraining multilateral arrangement. While this scheme appeared initially to be sound, subsequent events suggested that the Chinese were not prepared to be "constrained" or "engaged" on terms set down by ASEAN.

\section{Economic Implications for ASEAN}

Huge potentials have been explored through the signing of the free trade agreement between China and ASEAN that came into effect in 2010. Apart from the two- way trade between China and ASEAN, the agreement has also promoted the development of tourism and cultural exchanges between the two sides. At the ASEAN summit held in November 2012 Southeast Asian leaders sought to ease tensions with China over Spratly island and other maritime disputes as China and Japan spar over Diaoyu/ Senkaku islands further to the north, risking damage to trade ties between Asia's biggest economies. Chinese Premier said that maritime disputes should not make an obstacle for the success of their free trade partnership with ASEAN and resisted talks with ASEAN on a legally binding code of conduct in the South China Sea. China has deployed maritime surveillance ships to assert its territorial claims. The Philippines and Vietnam, which have awarded exploration contracts to Exxon Mobil Corp. (XOM), Talisman Energy Inc. (TLM) and Forum Energy Plc (FEP), reject China's map of the sea as a basis for joint development of oil and gas. ASEAN had failed to reach consensus

13 Michael Leifer, "Truth About the Balance of Power," in Structure, Singapore: Institute of Southeast Asian Studies, 1996, pp 50-51. 
on handling the South China Sea disputes at a July meeting, marking the first time in its history that it failed to release a communique.

Two important decisions at the recently concluded 21st ASEANSummit in Phnom Penh were: the launch of the ASEAN Regional Comprehensive Economic Partnership (RCEP) and delaying the launch of the ASEAN Economic Community (AEC) by twelve months, from January 1 to December 31, 2015, to iron out pending issues and prepare the necessary regulations. RCEP is forged as an alliance between ASEAN and its six dialogue partners -- Australia, China, India, South Korea, Japan and New Zealand -- to create a free trade area with great potential for gains through economic cooperation. To date, numerous free trade agreements (FTAs) and economic partnership agreements (EPAs) have been concluded between single ASEAN member nations and by ASEAN as a group with individual dialogue partners. However, the overlapping priorities, procedures and practices have reduced the effectiveness and the potential benefits of these agreements since businesses have to observe the different rules of these various arrangements while it has also increased the cost of utilizing preferential concessions. It is in that context that the ASEAN's RCEP agreement, with its region-wide partners, has the potential to reduce the complexity arising from the current multiplicity of agreements by agreeing on a single package and focusing on ASEAN's centrality in the region. Second, RCEP would be a basis for more complementary regional integration initiatives, since the partnership is to be built on the experiences, strengths and drawbacks of the many existing FTAs and EPAs.

It is also hoped that the ASEAN's RCEP could spur efforts to set up an FTA between China, Japan and South Korea, a prospect faced with several impediments still to be resolved. Once established on a firm footing among the three Northeast Asian nations, it can certainly enhance further regional economic integration. All these positive aspirations and moves to achieve effective regional economic integration pivot on the countries concerned strengthening their commitment to, and being ready to work towards, that very goal, both among ASEAN members and their dialogue partners. The decision to delay by twelve months the launching of the AEC becomes critical. In that time frame, all ASEAN members must make progress to fulfill and implement the agreed road map and targeted actions for the AEC. That must surely be a prerequisite for realizing the broader goal of regional economic integration. RCEP might be perceived as a competitor to the United States-led Trans-Pacific Partnership (TPP). At present, only Australia, Brunei, Malaysia, New Zealand, Singapore and Vietnam are a part of the TPP, while several other ASEAN members and dialogue partners, notably China, are not -- a fact that could cause conflict of interests and derail effective economic integration. Such a situation, if not clearly demarcated so that both the TPP and RCEP mutually benefit its members, could easily complicate further the existing and planned business pacts in the region, and frustrate efforts to achieve effective regional economic integration. Malaysia, as a founding ASEAN member, having successful economic ties with all major countries and given its presence in both the TPP and RCEP, can and should play a key role in helping to promote the success of the AEC and the wider goal of regional economic integration, especially in the current context of a globalised economic and trading regime.

It would only be in that particular circumstance that ASEAN would likely contemplate anything approximating a formal alliance arrangement to meet that threat. If a state suddenly becomes more assertive it can frighten its neighbors. Eventually, the 
neighbors are likely to respond by forming an alliance to contain the threatening state like a rising China. In so far as Southeast Asia is concerned this observation certainly has some historical resonance. Vietnam's December 1978 invasion of Cambodia, while not frightening non-communist Southeast Asia into forming an alliance to contain Vietnamese expansionism, certainly provided the catalyst for a joint ASEAN stand to confront, and lead world opinion against, Vietnam. A suddenly assertive China, however, could well provide coalescence in threat perceptions by the ASEAN states, resulting in the shelving of bilateral disputes so as to deal with the larger security issue that affects the whole of Southeast Asian economic integration with China and indeed the wider Asia-Pacific. Thus, China, contingent on its future regional behavior, could well provide the spark for a significant strategic rationale to ASEAN, and a unified strategic policy for the grouping. Because Southeast Asia is growing more reliant on trade with China, this is a gateway for shipments to advanced economies.

China needs to invest and transfer their technologies to ASEAN region to offset the trading deficit and ASEAN countries need to improve their foreign investment environment in order to maintain sustainable trade partnership. ASEAN member states can take measures by shortening the permit application process, eradicating corruption and by adopting transparency in implementing economic policies. China and the ASEAN countries have diverse resources, skills, strengths and talents that could be shared and developed into core competencies and capabilities for domestic businesses to thrive in the regional and global market, given the global economic downturn that stemmed from the US financial crisis and euro zone debt debacle.

\section{Conclusion}

In the near to medium term, the ASEAN countries will most likely adopt a suitable deferential stance in relations with their large northern neighbors like China. China is expected to exert a greater economic, cultural and diplomatic influence in what it considers its "backyard" over the coming decade. Beyond the near to medium term, however, things are less clear. Nothing in the ASEAN experience suggests that the grouping subscribes to principles which are inflexible. In the conduct of their international relations the ASEAN countries will likely give China substantial freedom of action so long as it does not lead to a situation of conflict or Chinese interference in the sovereign rights and affairs of member-states. The question that naturally arises is whether by that time China's strength would have grown to such proportions that ASEAN, as a collective entity, would be unable to stem China's ability to dictate terms. The answer to this question is likely to become clearer perhaps in a decade from now. Until then, a mix of pragmatism, adroit diplomacy, internal cohesion and expanding economic and military capabilities will be the predominant ASEAN approach in its relations with the China or any other aspiring major power in the Asia-Pacific.

Asia's regional groups like the ASEAN Regional Forum or the East Asian Summit facilitate the peaceful engagement of great powers with each other and with the region, without reducing weaker states to the status of vassals and pawns. The rise of China requires adjustments and strengthening of the present order. The revival of a new and tributary order with the resurgent China is likely to be countered by the economic, strategic and cultural influence of the US, Japan, India and Russia. It is argued that Asia and Australia are better served by a model based on the kind of 
'entrepreneurial' and 'intellectual' leadership to which Japan, Australia and ASEAN (now South Korea, Indonesia and India) have made a contribution, and which has brought about the simultaneous engagement of China and the US. Member countries of ASEAN are concerned about the fallout of potential conflicts between the US and China if China becomes more expansive or the US decides to adopt a more aggressive containment policy toward Beijing. These counties are also worried about a war over Taiwan which could destabilize the whole region and force the countries to align with either side. However, it seems that China cooperates and stimulates ASEAN's economic interdependence, as do the US, Japan and India. The US has also sought to build trade ties with ASEAN countries through the TPP. Moreover, the presence of the US in the Asia-Pacific to ensure stability and India's increasing economic might can offer a check and balance against any future uncertainty of a resurgent China in Southeast Asia.

\section{References}

Amitav Acharya, "The ARF Could Well Unravel," in da Cunha (ed.), The Evolving Pacific Power Structure, Singapore: Institute of Southeast Asian Studies, 1996.

Andrew Selth, "The Myanmar Army Since 1988: Acquisitions and Adjustments," Contemporary Southeast Asia, vol.17, no.3, December 1995, pp.249-250.

Bertil Lintner, "Burma: Centrifugal Forces," Far Eastern Economic Review, 27 February 1992, p.16. See also J. Mohan Malik, "Sino-Indian Rivalry in Myanmar: Implications for Regional Security," Contemporary Southeast Asia, vol.16, no.2, September 1994, p.139;

Barry Buzan, The United States and the Great Powers, Cambridge: Polity, 2004, pp. 107-31.

Colin S. Gray, "The Continued Primacy of Geography," Orbis, vol.40, no.2, Spring, 1996, p.258.

Chu Shulong, "The PRC Girds for Limited, High-Tech War," Orbis, vol.38, no.2, Spring, 1994.

David Shambaugh, "Growing Strong: China's Challenge to Asian Security," Survival, vol.36, no.2, Summer 1994, p.53.

Derek da Cunha, "Strain Ahead Between China and Japan," International Herald Tribune, 21 July 1993, p.6.

Derek da Cunha, "What China's 'Local' War Doctrine Means for East Asian Security," The Straits Times, 5 August 1993, p.26.

Deng Haiyan and Robert McGuckin, “The Dynamics of China's Labor Market: Job Creation and Destruction in the Industrial Sector," East Asian Economic Perspectives, Vol. 16, No.-1, 2005. 
2 (August), pp. 58-92.Fitzgerald, C.P. The Southern Expansion of the Chinese People London: Barrie \& Jenkins, 1972.

Gerald Segal, "East Asia and the 'Constrainment' of China," International Security, vol.20, no.4 Spring, 1996, p.123.

33

Haacke, J., "The Significance of Beijing's Bilateral Relations: Looking 'Below' the Regional Level in China-ASEAN Ties," in H. K. Leong \& S. C. Y. Ku (Eds.), China and Southeast Asia: Global Changes and Regional Challenges. Singapore: Institute of Southeast Asian Studies, 2005.

Hamzah, B. A., China's "Tibetization" of the South China Sea. Quoted in Barry Wain, "Beijing and Hanoi Play With Fire in South China Sea," The Asian Wall Street Journal, 20 July 1994, p.5.

Jonathan Pollack, “The Men But Not the Guns," Far Eastern Economic Review, 18 December 1981, p.28.

Johnston, A. I. Social States: China in International Institutions, 2007, 1980-2000.

Jones, D. M., \& Smith, M. L. R., Constructing communities: the curious case of East Asian regionalism, 2007, Review of International Studies 33(1).

Katsumata, H., Establishment of the ASEAN Regional Forum: constructing a 'talking shop' or a 'norm brewery'. The Pacific Review, 19(2), 181 - 198, 2006.

Katsumata, H, Correspondence: ASEAN, Regional Integration, and State Sovereignty. International Security, 33(2), 2008.

Kuik, C., The essence of hedging: Malaysia and Singapore's response to a rising China. (Report). Contemporary Southeast Asia, 30(2), 159(127), 2008.

Lardy, Nicholas, "China: Rebalancing Economic Growth," chapter 1 in The China Balance Sheet in 2007 and Beyond, published by the Center for Strategic and International Studies and the Peterson Institute for International Economics (May), 2007, pp. 1-24.

Liow, J. C., Balancing, Bandwagoning, or Hedging? Strategic and Security Patterns in Malaysia's Relations with China,1981-2003. In H. K. L. a. S. C.Y.Ku (Ed.), China and Southeast Asia: Changes in Strategic Perceptions Singapore: Institute of Southeast Asian Studies, 2005.

Mark J. Valencia, China and the South China Sea Disputes, Adelphi Paper 298, (London: International Institute for Strategic Studies, 1995), pp.6-7. 
Muthiah Alagappa, 'Preface', and 'Managing Asian Security: Competition, Cooperation and Evolutionary Change', in Muthiah Alagappa, ed., Asian Security Order, pp. ix-xv,

Murray Hiebert, "Hanoi's Tit for Tat," Far Eastern Economic Review, 30 June 1994, pp.2021.

Ngok Lee, China's Defense Modernization and Military Leadership (Canberra: Australian National University Press, 1989), especially pp.3-41.

Rizal Sukma, "Recent Developments in Sino-Indonesian Relations: An Indonesian View," Contemporary Southeast Asia, vol.16, no.1, June 1994, pp.40-41.

Rizal Sukma, "China's Defense Policy in the Asia Pacific," The Indonesian Quarterly, vol.23, no.1, p.82.

Sakamoto, Hiroshi and Nazrul Islam, "Convergence across Chinese Provinces: An Analysis Using Markov Transition Matrix," China Economic Review, Vol. 19, 2008, pp. 66-79.

Shambaugh, D. China Engages Asia: Reshaping the Regional Order. International Security, 2004, 29(3).

Stubbs, R. The ASEAN alternative? Ideas, institutions and the challenge to 'global' governance, 2008, The Pacific Review, 21(4).

The Straits Times, 23 April, 2013.

Vijayan Menon, "PM: Closer Economic Links with China Can Only Bring Good," New Straits Times, 1 May 1993, p.2.

William A. Callahan, 'How to Understand China: the Dangers and Opportunities of Being a Rising Power', Review of International Studies, Vol. 31, No. 4, 2005, pp. 701-14. 